\title{
KEPADUAN UNSUR VERBAL DAN NONVERBAL DALAM MEME INSTAGRAM BERBAHASA ARAB: ANALISIS WACANA
}

\author{
Moh. Masrukhi \\ moh_masruhi@ugm.ac.id \\ Program Studi Sastra Arab Fakultas Ilmu Budaya \\ Universitas Gadjah Mada Yogyakarta
}

\begin{abstract}
Meme Instagram generally uses two views, as well as verbal and nonverbal text. This article will reveal the verbal and nonverbal structure of the Instagram meme. The aim is to find out what are the elements of meme its pattern and how the interrelationships between these elements are interrelated and aligned together into one unit. The meme data is taken from the @ Mzajeat instagram and @ Iq.Shabab which is in Arabic. Furthermore, the data is analyzed by utilizing concepts or theories of discourse and semantics. The result is the opening element of memes can be verbal or nonverbal elements, as well as the body or contents of memes can be in the form of verbal or nonverbal elements. From this research, it can be argued that the integration or linkage and the existence of these two elements make memes a discourse that is very interesting and very diverse in interpretation, especially on nonverbal elements. Through these two elements the meaning and message of the meme writer can be conveyed.
\end{abstract}

Keywords: memes, verbal elements, nonverbal elements.

$$
\begin{aligned}
& \text { ملخص } \\
& \text { يستخدم ميمي الإنستغرام عموما عنصرين وهما العنصر اللفطي والعنصر غير اللفطي. تتناول هذه المقالة تركيب }
\end{aligned}
$$

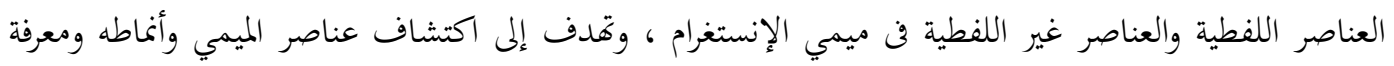

$$
\begin{aligned}
& \text { كيفية تركيب العلاقات الداخلية بين هذه العناصر في هيئة واحدة . تؤخذ بيانات الميمي من مستخدم الإنستغرام }
\end{aligned}
$$

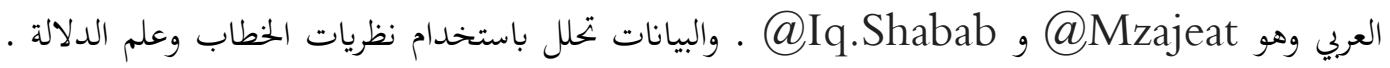

$$
\begin{aligned}
& \text { وتشير نتائج التحليل إلى أن الجزء الفاتح أو المقدمة من الميمي يتكون من العناصر اللفظية وغير اللفظية ، وإلى أن بان }
\end{aligned}
$$

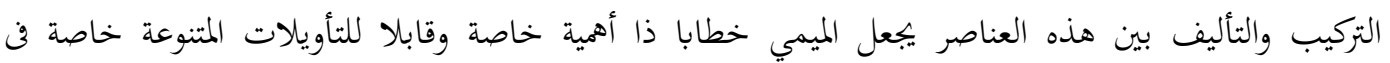

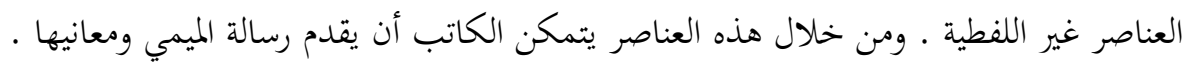

$$
\begin{aligned}
& \text { الكلمات المفتاحية : الميمي ، العناصر اللفظية ، العناصر غير اللفظية . }
\end{aligned}
$$

\section{Pendahuluan}

Bahasa, kata Danesi (2011:107108) adalah sebuah fenomena yang sangat luar biasa. Secara universal, bahasa selalu dirasakan sebagai memiliki kapasitas yang lebih dari kapasitas lain, membedakan manusia dengan spesies yang lain. Tanpa 
bahasa tidak dapat dibayangkan bagaimana manusia ini hidup. Tanpa bahasa bagaimana manusia dapat berinteraksi atau berkomunikasi dengan yang lainnya. Karena hanya dengan bahasalah yang dapat mereka gunakan untuk menyampaikan gagasan pemikiran atau pesanpesannya (communicate ideas) kepada orang lain. Selanjutanya, kata Danesi bahasa bukanlah sekedar kumpulan kata-kata saja ketika ia digunakan untuk maksud representasi atau komunikasi. Kata itu memungkinkan orang menjadikannya sebagai perantara pesan dengan cara yang sangat kuat. Selain itu, bahasa digunakan untuk membangun kebersamaan yang harmonis dan menyenangkan dengan manusia lainnya (Crystal, 1987:10).

Dalam hal ini para pakar semiotik menganggap teks verbal adalah kata-kata yang dipergunakan untuk menyampaikan gagasan, ide, atau pesan-pesan yang lain. Mengingat fungsi tersebut mereka juga menganggap bahwa teks verbal tidak ada bedanya dengan teks nonverbal. Ternyata manusia mempunyai banyak mode komunikasi, baik komunikasi verbal maupun nonverbal, seperti komunikasi dengan isyarat, kerlingan mata, atau ekspresi-ekspresi lain yang menyertakan gerak tubuh yang disebut sebagai paralanguage.

Dari sinilah perlu kiranya dibedakan antara bahasa dan ujaran. Ujaran adalah fenomena psikologis dan anatomis yang melibatkan organ peralatan vokal secara sengaja, seperti lidah, gigi, dan sebagainya untuk mengartikulasikan bunyi dan kata. Sementara bahasa adalah sebuah kode mental. Ia adalah sistem tanda yang biasanya menghantarkan ujaran vokal, tetapi ia juga dapat diekspresikan melalui mode fisis (phisically mode), seperti piktografi, isyarat, dan sebagainya (Danesi, 2011:110-111).

Sebagaimana disebutkan di atas bahwa bahasa sebagai alat komunikasi bagi masyarakat sosial pemakainya. Bahasa digunakan untuk menyampaikan informasi, baik melalui lisan ataupun tulisan oleh penggunanya sehingga dapat dimengerti oleh orang yang diberi informasi (Wijaya, 1997:11; Badudu, 1992:54). Informasi atau gagasan tersebut dapat disampaikan melalui berbagai media, seperti media sosial yang kini sudah menjamur di berbagai penjuru dunia. Salah satunya adalah melalui meme Instagram.

Meme adalah coretan-coretan gambar, foto, dan karakter tertentu. Coretan-coretan tersebut kadang mengandung rasa humor, sindiran, kadang juga permasalahan dalam kehidupan (Amrullah, 2013:14). Selain itu, meme juga dapat berfungsi sebagai alat untuk mengekspresikan diri, memberikan informasi, dan juga sebagai sarana motivasi tertentu kepada pembaca atau lawan tutur.

Di era kemajuan teknologi komunikasi saat ini, banyak bermunculan meme-meme yang semula berbahasa Inggris kemudian diikuti oleh bahasa-bahasa lain, seperti meme bahasa Arab. Meme bahasa Arab juga ditemukan di jejaring sosial, seperti Facebook, Twitter, dan Instagram. Instagram sendiri adalah sebuah aplikasi media sosial untuk barbagi foto dan video yang memungkinkan pengguna mengambil foto maupun video dari instagram tertentu dan membagikannya ke berbagai layanan jejaring sosial.

Sebagai sarana komunikasi, penampilan meme di Instagram terdiri atas dua unsur, yakni teks verbal dan 
nonverbal. Terkait dengan unsur nonverbal peneliti mengikuti teori Cook (1994:1) yang berpendapat bahwa semua bentuk ekspresi komunikasi, seperti ucapan, musik, gambar, efek suara, dan sebagainya adalah teks. Ucapan kata-kata masuk kategori teks verbal, sedangkan gambar masuk dalam kategori nonverbal. Kedua unsur inilah kemudian terdistribusi pada elemenelemen meme instagram. Unsur-unsur itu juga sekaligus menjadi penggerak dan memberi ruh kepada meme itu dan membentuk makna yang utuh dan menarik. Makna dan pesan meme itu yang kemudian dapat diinterpretasikan oleh pembacanya (Masrukhi, 2016:195) atau penggunanya. Seperti halnya iklan, unsur teks (verbal) dalam meme kiranya juga dianggap lebih efsien dan penting (Dyer, 1989:139) karena tidak mengenal batasan ruang dan waktu (Keraf, 1991:18). Sementara unsur nonverbal yang berupa visual, seperti gambar atau ilustrasi, juga menjadi sangat penting karena memiliki pengaruh yang kuat untuk dapat memahami pesan yang ingin disampaikan pembuat meme itu sendiri. Perpaduan unsur-unsur meme yang semacam ini tentunya juga bukan sebagai perpaduan tanda semata lagi, melainkan sebuah rangkaian rekaman kebahasan yang utuh tentang peristiwa komunikasi sebagaimana dikatakan Samsuri (1987/1988:1).

\section{Paradigma Keilmuan}

Setiap bahasa memiliki perbendaharaan kata yang sangat besar. Setiap kata (leksem) memiliki arti atau makna. Kata atau leksem, dalam struktur yang lebih besar, merupakan bagian kalimat. Kalimat sendiri selalu dikatakan sebagai susunan atau gabungan dari beberapa kata yang memiliki satu pengertian tertentu dengan intonasi sempurna. Menurut Gie dan Widyamartaya (1983:92) berdasarkan aspek semantisnya kalimat memiliki makna sebagai serangkaian kata yang menyatakan pikiran atau gagasan yang lengkap dan logis.

Jika kata-kata bermakna yang disebutkan di atas dirangkai kemudian mengandung tema-tema tertentu, maka hal tersebut disebut dengan teks. Brown dan Yule (1983a:6) mengatakan bahwa kata-kata itu yang akan kita gunakan untuk menginterpretasikan makna dan (istilah) teks akan kita gunakan sebagai terminologi teknis untuk mengacu bentuk komunikasi verbal dan juga nonverbal (Cook dalam Wijana, 2009:72). Bentuk realisasi komunikasi lisan, seperti percakapan, ritual keagamaan, transaksi belanja, dan asebagainya, sedangkan dalam bentuk tulis, seperti teks pidato, poster, iklan, meme, dan sebagainya.

Penggunaan bahasa (verbal) dalam meme selalu disertai dengan gambar (nonverbal). Penggunaan dua unsur tersebut ditunjukkan agar para pengguna atau follower instagram tertarik (persuasif) mengikuti pemikiran, gagasan, atau gambarangambaran peristiwa yang sedang terjadi di sekitar para pengguna instagram tersebut. Sementara pemanfaatan unsur nonverbal berupa gambar dan ilustrasi ini dipandang sangat penting karena memiliki pengaruh yang lebih kuat daripada unsur verbal. Unsur nonverbal dapat ditangkap tanpa perhatian (kesadaran) yang penuh dan tanpa memerlukan rumusan verbal yang eksplisit (Masrukhi, 2016:91). Pevroutet (dalam Santosa, 2006:50) juga mengatakan bahwa untuk mencapai keefektifan, 
kecepatan, dan penerimaan pesan yang lebih konkret, orang cenderung memilih berkomunikasi melalui gambar (nonverbal), seperti iklan di media cetak. Namun, gambar tersebut setidaknya disertai satu teks verbal, seperti judul dan sebagainya. Di sini teks verbal berfungsi sebagai fasilitas pendukung untuk memahami teks nonverbal itu sendiri karena unsur ini dalam komunikasi, baik yang wajar, alami, atau rekaan, seperti bahasa meme merupakan unsur yang utama (Effendy, 1993:177).

Selanjutnya, meme itu sendiri disebut sebagai wacana adalah ketika meme itu dilihat sebagai sebuah bentuk media komunikasi. Peristiwa komunikasi melalui meme terbangun dari seperangkat unsur teks verbal maupun unsur teks nonverbal. Rangkaian peristiwa itu mempunyai pengertian yang lengkap dan padu. Hal ini didasarkan pada pandangan Cook (2001:3) bahwa bahasa (verbal) yang digunakan untuk berkomunikasi adalah wacana dan pandangan Littlejohn bahwa bentuk-bentuk nonverbal dapat juga dianggap sebagai wacana karena muncul di dalam konteks (Littlejohn, 1996:84-85). Dari itu, wacana tidak hanya konsen pada aspek bahasa saja, tetapi juga mengkaji konteks komunikasi. Dengan demikian, unsur-unsur verbal dan nonverbal pada meme Instagram ini akan lebih tepat jika dikaji secara semantik (context independent), di samping sebagai sebuah wacana (context dependent).

\section{Metode Penelitian}

Setiap penelitian tentu memerlukan pijakan teori dan metode agar dapat menuntun arah dan cara kerja yang sesuai dengan permasalahan dan tujuan yang telah digariskan. Sebagaimana disebutkan secara sekilas di atas bahwa spesifikasi data yang diambil dalam penelitian ini adalah meme instagram pada @Mzajeat \& @Iq.Shabab. Data yang diperoleh memiliki dua unsur, yaitu unsur verbal dan unsur nonverbal. Sementara yang diperlukan adalah kesesuaian dan kepaduan makna pesan, baik aspek verbal (bahasa) maupun aspek noverbalnya. Untuk mengungkap makna dan pesan yang ingin disampaikan melalui struktur teks meme, baik teks verbal maupun nonverbalnya, peneliti menggunakan metode padan dengan teknik dasar pilah unsur penentu, yaitu dengan daya pilah yang bersifat mental (referensial). Tahapan ini pada dasarnya adalah mengamati bagaimana bahasa digunakan pada tataran konkrit (parole).

Dalam analisis data dua unsur pembentuk wacana tersebut akan dianalisis secara berurutan. Pertamatama akan dianalisis unsur verbalnya, terutama pada elemen 'headline' atau judul dan elemen 'bodycopy' atau tubuh. Selanjutnya, dilakukan analisis nonverbalnya, yaitu elemen ilustrasi atau gambar yang disertakan. Berikutnya, karena keseluruhan unsur dan elemen dalam meme instagram tersebut merupakan sebuah wacana dan wacana mengandung teks verbal dan teks nonverbal (Halliday, 1992; Cook, 1994; Wijana, 1996; Mulyawan, 2010; Eriyanto, 2011; Hasan, 2009), maka analisis wacana yang tepat digunakan untuk membedahnya adalah metode tekstual.

Metode tekstual dipadu juga dengan metode kontekstual, yaitu cara analisis yang diterapkan pada data (kebahasaan) yang terkait dengan konteks yang melingkupinya, yaitu konteks pragmatik. Dalam hal ini 
Malinowski (1923) mengatakan bahwa konteks itu dinamis bukan konsep statis, dalam memahami lingkungan teks (dalam Halliday, 1992:7) dan latar belakang pengetahuan yang dimiliki bersama oleh penutur dan mitra tutur untuk mengekspresikannya melalui bahasa dalam komunikasinya sehingga saling dimengerti (mutual intelligible). Jadi, teks (verbal) dalam meme tersebut dianalisis dan dipadukan dengan konteks (nonverbal atau visualisaisinya). Dengen begitu sekaligus dapat menemukan pesan dan makna meme instagram @Mzajeat \& @ Iq.Shabab.

\section{Pembahasan}

Sebagaimana disebut di depan bahwa meme dalam instagram merupakan bentuk komunikasi yang isinya adalah gabungan unsur-unsur dan elemen-elemen. Yang dimaksud unsur dalam penelitian ini adalah unsur teks (verbal) dan unsur visual berupa gambar atau ilustrasi (nonverbal), sedangkan elemen adalah bagian-bagian tertentu dalam meme yang menjadi rumah unsur-unsur ini. Kedua aspek inilah yang yang memberikan ruh pada sebuah meme. Kedua aspek itulah yang membangun sebuah bangunan yang saling mengisi, saling mendukung, dan mengait satu dan lainnya sehingga memiliki makna dan pesan yang dapat dipahami oleh pengguna instagram dan juga followernya. Tujuannya adalah untuk menarik perhatian dan memikat hati pengguna.

Sebagaimana dinyatakan oleh Luxemburg (1984:100) di depan bahwa wacana dihasilkan oleh proses komunikasi yang bertautan dan saling berhubungan satu elemen dengan elemen lainnya, mulai dari awal, tengah, sampai akhir. Tahapan- tahapan komunikasi itu juga akhirnya menentukan struktur wacana sehingga wacana juga memiliki elemen-elemen pembangun yang melengkapinya.

Dalam wacana meme instagram berbahasa Arab ini elemen-elemen tersebut adalah elemen awal, yaitu elemen yang menjadi pembuka wacana, elemen tengah adalah tubuh wacana atau bodycopy. Elemen ini berfungsi sebagai penjelas pernyataan pada elemen awal. Pada elemen bodycopy inilah penjelasan utama bagi pernyataan yang disampaikan pada elemen sebelumnya. Pada elemen ini juga sekaligus menjadi penutup dan penanda akhir wacana meme instagram pada@Mzajeat \& @Iq.Shabab.

Elemen-elemen dalam meme instagram berbahasa Arab dalam data yang ditemukan yang pertama adalah elemen pembuka. Elemen ini dapat berupa unsur verbal atau non verbal, begitu juga elemen berikutnya adalah elemen bodycopy yang dapat berupa unsur verbal ataupun unsur nonverbal.

Struktur meme instagram pada @Mzajeat \& @Iq.Shabab ini terdiri atas unsur verbal dan nonverbal. Unsur-unsur ini tarbagi dan tersebar pada elemen-elemen pendukung wacana, yaitu elemen pembuka serta elemen tubuh yang dimaksudkan untuk menjelaskan isi secara keseluruhan. Pada elemen tubuh ini juga sekaligus menjadi elemen penutup.

\section{Elemen Pembuka (judul)}

Pembuka adalah elemen yang paling awal muncul dalam sebuah wacana. Pembuka dalam meme ini adalah judul (title), yaitu kepala karangan, kepala cerita, kepala pekabaran, dan sebagainya (KBBI, 2013:394). Sifat judul title ini penting 
karena merupakan pengait hook dengan elemen berikutnya sekaligus pengait dengan unsur nonverbal (Masrukhi, 2016:98). Peran hook untuk menciptakan suspense atau kejutan sekaligus menarik perhatian (eye cacher) (Bathia, 1992:196). Sebagai pembuka, hook tugasnya hanyalah untuk 'merangsang' benak pengguna instagram. Hook lebih baik pendek, tetapi orisinal dan memikat khalayak sehingga dapat dengan cepat dipahami dan menganalisis pesannya hanya dengan sekilas melihat kedua hal terebut (unsur verbal dan nonverbal). Misalnya:

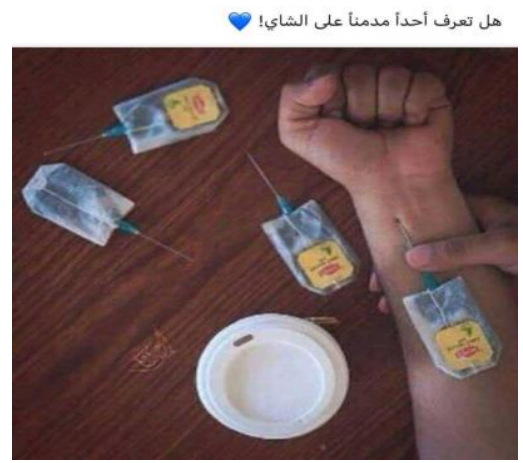

1)

$$
\text { هل تعرف أحدا مدمنا على الشاي؟ }
$$

Ihal tårifu achadan mudminan ‘ala asy-syai?/

'Pernahkah Anda tahu orang kecanduan teh?'

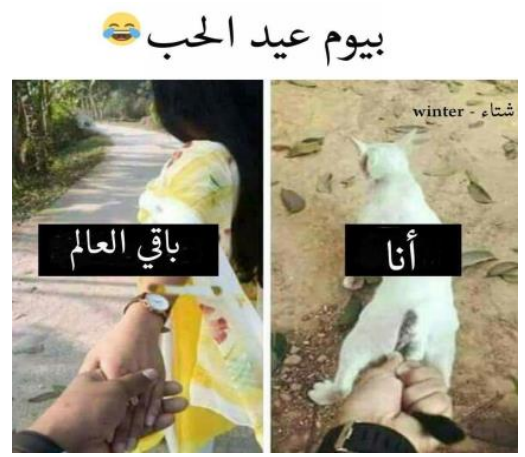

2)

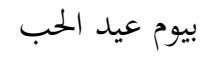

\section{/biyaum `idil chub/}

'Di Hari Valentaine'

Jika diperhatikan pada contoh meme (\#1) di atas pembukanya terdiri atas unsur verbal, yaitu kalimat interogatif 'Pernahkah Anda tahu orang kecanduan teh? Kalimat ini tentu saja menimbulkan pertanyaanpertanyaan. Oleh karena itu, dengan pertanyaan-pertanyaan yang muncul tersebut perlu ada penjelasannya. Di sinilah hook atau pengait berperan, yaitu merangsang benak mitra atau pengguna Instagram lainnya menjadi bertanya-tanya. Dari pertanyaan tersebut, maka diperlukan penjelasan yang disampaikan melalui judul tersebut. Dengan harus ada elemen lain yang tugasnya menjelaskan, apa yang dimaksud dengan pertanyaanpertanyaan yang mungkin muncul itu. Di sinilah tubuh atau bodycopy berperan sebagai penjelas atau menjawab pertanyaan yang dikemukakan pengguna atau pemirsa. Pada contoh meme (\#2) berikutnya yang menjadi judul adalah konstruksi idhāfi (frasa nominal posessif/FNP) biyaum 'idil chub 'Di Hari Valentine'. FNP dalam meme ini dikatakan sebagai pembuka karena memang secara jelas posisinya ditempatkan di awal meme atau tempat paling atas, yaitu sebelum elemen yang lain dimunculkan. FNP pada contoh meme (\#2) di atas sebagai judul tidak mempunyai makna atau pesan tertentu kepada pengguna instagram, kecuali sebuah pernyataan belaka. Adanya FNP tersebut memunculkan berbagai pertanyaan yang memerlukan penjelasan lebih lanjut, seperti ada peristiwa apa di hari tersebut?, siapa yang terlibat dalam peristiwa tersebut?, bagaimana kejadiannya?, dan sebagainya. 
Pembuka wacana dalam meme instagram pada @Mzajeat \& @ Iq.Shabab ini dapat berupa unsur verbal maupun nonverbal. Contohnya:

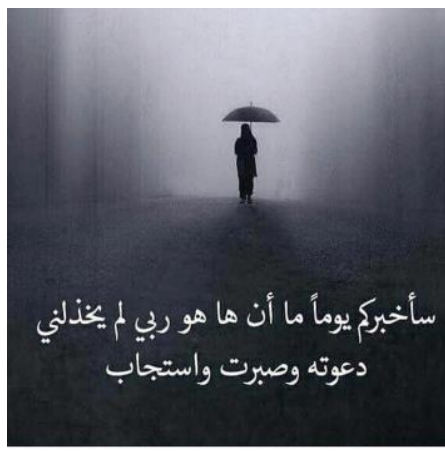

3أخبركم يوما ما أن ها هو ربي لم يخذلنى (3) دعوته وصبرت واستجاب

Isa'ukhbirukum yauman mā anna hā huwa rabbī lam yakhzhuln̄ da'autuhū wa shabartu wastajāba

"Akan saya kabarkan kepada kalian suatu hari bahwa inilah Tuhanku tidak menyianyiakanku. Saya berdoa dan bersabar, kemudian Dia mengabulkannya."

Elemen judul pada contoh meme (\#3) di atas dapat dikatakan terdiri dari unsur nonverbal karena tampak jelas di situ adanya ilustrasi atau gambar. Mengapa unsur nonverbal atau gambar karena pada kenyataannya unsur inilah yang mengawali wacana meme ini, yaitu sebuah ilustrasi. Ilustrasi tersebut menggambarkan sesosok orang yang memakai payung untuk melindungi dirinya, dia sedang berjalan dari tempat yang gelap menuju tempat yang lebih terang, mungkin juga menuju terik matahari ataupun dari tempat yang tidak hujan menuju tempat yang sedang diguyur air hujan. Selanjutnya, jika diperhatikan secara seksama lagi ilustrasi tersebut, dari bentuk postur sosok itu, baju yang dikenakan, cara berjalannya atau ciriciri yang bisa diperhatikan dari sosok tersebut. Dari itu dapat disimpulkan bahwa sosok tersebut adalah sebagai sosok perempuan. Sosok perempuan tersebut sedang berjalan, dari sisi gelap menuju ke sisi yang lebih terang, atau bisa juga dari posisi yang terlindung ke posisi yang tak terlindung dari terik matahari, dari posisi tidak hujan menuju posisi yang sedang hujan deras. Dari itu, sosok seorang perempuan ini sudah menyiapkan diri dengan menggunakan sebuah payung untuk melindungi dirinya dari sengatan matahari atau dari guyuran badai dan hujan, atau bisa juga dikatakan sebagai perjalanan seorang manusia, dari gelap menuju ke tempat yang terang benderang, dan sebagainya.

\section{Elemen Tubuh (bodycopy)}

Tubuh (bodycopy) atau isi sebuah wacana adalah tempat menyelesaikan pertanyaan atau pernyataan yang dikemukakan atau masalah tertentu yang sengaja diungkapkan oleh hook atau judul (Masrukhi, 2016:98). Oleh karena itu, tubuh atau bodycopy harus mempunyai pesan yang pandai dan meninggalkan kesan yang kuat. Pada umumnya elemen bodycopy dalam meme instagram berupa unsur nonverbal. Pada contoh meme (\#1) di atas yang menjadi tubuh atau bodycopynya terdapat subjudul untuk menjelaskan peristiwa yang terjadi pada judul tersebut, yaitu:

3a) ن

lanal

'Saya' 
yang kemudian dibandingkan dengan frase nominal posessif atau tarkib idhafi:

$$
\begin{aligned}
& \text { باقي العالم } \\
& \text { /baqial ‘alam/ } \\
& \text { 'di tempat lain’ }
\end{aligned}
$$

Dari pernyataan itu kemudian dapat dibandingkan antara keadaan elemen bodycopy dengan subjudul ana 'aku' dan elemen bodycopy dengan subjudul FNP bāqi al- 'alam 'di tempat lain', 'orang lain', dan sebagainya.

Tubuh atau bodycopy dalam contoh meme (\#2) ini terdapat dua elemen sebagai pengisinya. Masingmasing elemen memiliki subjudul dan bodycopy yang terdiri atas unsur verbal dan juga nonverbal, tetapi pada hakekatnya keduanya adalah satu kesatuan karena keduanya memiliki pesan dan makna yang saling berhubungan, yaitu adanya hubungan koordinatif antara ilustrasi yang satu dengan yang lainnya.

Pronomina persona ana 'saya' merupakan unsur verbal dan menjadi subjudul pada ilustrasi di sebelah kanan, dan FN (pertautan lokatif) baqial 'alam 'di tempat lain' juga sebagai subjudul pada ilustrasi di sisi kiri. Dalam bodycopy tersebut keduanya memiliki hubungan koordinatif. Ilustrasi sebelah kanan adalah seekor kucing putih, ekornya yang sedang dalam pengangan seseorang, seolah menarik tangan yang sedang memeganginya. Bila diperhatikan dengan sekasama (dengan ciri-ciri yang tampak), tangan ini adalah jenis tangan laki-laki. Si kucing seolah sedang menarik tangan laki-laki di belakangnya untuk diajak pergi. Ke arah mana perginya, tetapi tidak jelas jalannya, di hadapannya hanya terbentang lantai datar dan daun-daun berserakan di mana-mana.

Sementara ilustrasi yang ada di sebelah kiri, tampak tangan seorang wanita muda, tangannya putih bersih, mengenakan arloji yang bagus. Tangan perempuan dijulurkan ke tangan laki-laki, saling terhubung dengan mesra meskipun tangan satunya tampak kekar dan hitam. Ini menandakan bahwa tangan tersebut adalah tangan seorang laki-laki. Tangan laki-laki ini tampak di ujung lengannya sedang mengenakan pakaian jas warna abu-abu. Ini dapat diinterpretasikan sebagai suatu keseriusan hubungan dua sejoli. Dari ilustrasi ini si perempuan sedang menarik tangan laki-laki untuk diajak menapak jalan yang tampak jelas membentang di depannya. Jalan tersebut tampak bersih dan berbelok di ujung sana.

Hubungan yang terjalin antara judul utama dengan subjudul di bawahnya serta bodycopynya tampak sekali keterkaitan yang sangat erat. Begitu pula jika diperhatikan dari sudut pandang hook atau pengait antara judul dan subjudul dengan unsur nonverbal dalam meme tersebut sudah memenuhi kriteria, yaitu perhatian pengguna instagram yang semula tertuju pada bentuk verbal saja, pasti kemudian menyeberang dan beralih ke unsur yang berada di bawahnya, yaitu unsur nonverbal. Awalnya, yang terjadi adalah pengguna instagram tidak paham apa yang dimaksud dalam judul atau subjudul tersebut. Ada apa dengan bulan Valentine? Hari Raya Cinta? Apa yang dimaksudkan itu?, dan sebagainya. Pasti mereka tidak akan menemukan jawabannya jika hanya melihat pada judul tersebut. Karena pembaca belum menemukan 
jawabannya itulah kemudian pembaca akan beralih ke bagian berikutnya yaitu kebawah, ke elemen visual yang ditampilkan. Dengan beralih ke elemen visual inilah, maka pembaca akan paham dan terang, apa sebenarnya yang dimaksud dengan tuturan 'yaum 'idil chub' di atas.

Dari penelitian ini juga ditemukan beberapa data dengan struktur yang hanya memiliki satu elemen saya, yaitu elemen bodycopy yang terdiri atas dua unsur pendukung, yaitu unsur verbal dan nonverbal. Contohnya:

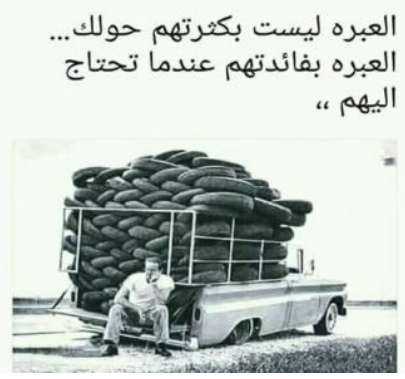

Dalam meme tersebut terdiri atas unsur verbal, yaitu klausa yang berbunyi:

4a)

$$
\begin{array}{ll} 
& \\
\text { lal } & \text { laibratu }
\end{array}
$$

bikatsratihim chaulak/

'Pelajaran, sesuatu itu bukan karena banyaknya yang ada di sekeliling Anda'

4b)

$$
\begin{aligned}
& \text { العبرة بفائدقم عندما تحتاج اليهم } \\
& \text { Ial ibratu bifa'idatihim } \\
& \text { indama tahtaju ilaih/ } \\
& \text { 'Pelajaran, sesuatu itu karena } \\
& \text { manfaatnya ketika } \\
& \text { diperlukan' }
\end{aligned}
$$

Jika diperhatikan dalam contoh meme (\#4) di atas tidak terdapat judul atau pembuka, melainkan langsung terdapat tubuh atau bodycopy sehingga judul dalam meme di atas tidak perlu dimunculkan. Judul untuk meme ini dipersilakan atau dapat dibayangkan sendiri oleh pengguna atau mitra tutur dalam media instagram tersebut. Pengguna diminta untuk memberi judul sendiri sesuai dengan yang dibayangkan ketika melihat atau memperhatikan meme ini.

Di samping itu, juga terdapat unsur nonverbal, yaitu ilustrasi yang menggambarkan kesedihan seorang laki-laki (sopir) yang sedang membawa tumpukan ban mobil dalam truknya. Namun, malang di tengah perjalannya ban mobil truknya pecah dan tidak bisa digunakan lagi, pompa mungkin tidak membawanya, tukang tambal ban juga barangkali jauh, dan sebagainya.

Dalam tubuh atau bodycopy meme tersebut antara unsur verbal dan unsur nonverbal memiliki pertautan atau pertalian makna atau hubungan koordinatif antara keduanya. Pertautan makna di sini dapat diperkirakan adanya yaitu penanda hubungan leksikal (Ramlan, 1993: 11) atau penanda hubungan koordinataif, yaitu 'tetapi'. Pertautan-pertautan antara elemen-elemen semacam itulah, baik unsur verbal dan nonverbal yang menyatu satu sama lain, kiranya sudah memenuhi kriteria yang disebutkan di atas, yaitu sebuah wacana.

\section{Makna Pesan}

Objek sebuah meme instagram merupakan representasi produk yang disebarkan kepada para pengguna instagram. Produk tersebut teridi atas unsur verbal dan nonverbal. Pertemuan dua unsur tersebut terdapat konteks. Konteks yang terdapat dalam sebuah meme merupakan elemen yang memberikan makna pada produk meme tersebut. Adapun teksnya befungsi untuk memperjelas 
hubungan makna dan pesan yang ingin disampaikan oleh pembuatnya. Jadi, pengungkapan makna dan pesan sebuah meme harus memperhatikan hubungan unsur-unsur verbal dan nonverbal dengan lingkungan sekitarnya (konteks meme) secara timbal balik, serasi, dan koheren.

Istilah koherensi memiliki makna 'pertalian' yang dalam konsep kewacanaan berarti pertalian makna atau isi meme. Koherensi juga berarti hubungan timbal balik yang serasi antarunsur dalam meme (lihat Keraf, 1984:38; Ramlan, 1993:9). Wacana yang koheren memiliki ciri-ciri: susunannya teratur dan amanatnya terjalin rapi sehingga mudah diinterpretasikan (Samiati, 1989:5 dalam Mulyana, 2005:30). Sementara Brown dan Yule (1983:224) menegaskan bahwa koherensi berarti kepaduan dan keterpahaman antarsatuan dalam suatu teks atau tuturan.

Koherensi sangat diperlukan dalam struktur wacana karena untuk menata pertalian batin antara unsur yang satu dengan unsur yang lainnya untuk memperoleh kesatuan dan keutuhan. Keutuhan yang koheren ditunjukkan adanya hubunganhubungan makna yang terjadi antarunsur tersebut secara semantik. Hubungan koherensi adalah suatu rangkaian fakta dan gagasan yang teratur dan tersusun secara logis dan dapat terjadi secara implisit (terselubung) karena berkaitan dengan makna yang memerlukan interpretasi (pemaknaan). Kebermaknaan wacana itu sebenarnya tergantung pada kelengkapan yang serasi antara teks dan konteksnya dalam tubuh wacana itu atau penyimpulan hubungan antarproposisi (Mulyana, 2005:31).
Secara struktural hubungan tersebut direpresentasikan oleh pertatutan secara semantis antara kalimat atau bagian yang satu dengan yang lainnya (Kridalaksana, 1978:3840). Hubungan maknawi itu kadangkadang ditandai oleh alat-alat leksikal, seperti pronomina, sinonim, konjungsi, koordinator, dan sebagainya, testapi kadang juga tidak ada penandanya, seperti hubungan sebab-akibat, hubungan waktu, hubungan perbandingan, dan sebagainya (Mulyana, 2005:31-32). Oleh karena itu, perlu pemaknaan atau interpretasi. Dari data yang diperoleh, misalnya meme instagram berikut dapat dimaknai atau diinterpretasikan sebagai berikut.

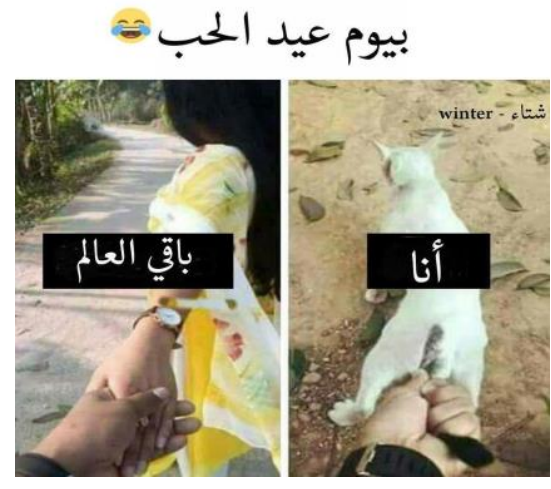

Data di atas (unsur verbalnya) adalah ana 'saya (seperti ini)', sedangkan (unsur nonverbalnya) ada jari-jari tangan tampak langsing. Ini menandakan bahwa jari-jari tersebut adalah jari-jari milik seorang wanita (gambar yang di sisi kanan). Di jari manisnya melingkar sebuah cincin. Ini dapat dipahami bahwa gambar yang sebelah kanan hanyalah hayalan atau angan belaka, sedangkan pada gambar sebelah kiri angan-angan sesuai harapan. Oleh karena itu, ungkapan pada unsur nonverbalnya dapat dimaknai sebagai kenapa nasib saya bisa seperti ini, menyedihkan, tidak adil, dan sebagainya. Sementara 
orang lain atau baqial 'alam 'orang lain' bahagia, menikmati keindahan hidup, berhasil bersatu dengan pujaan hatinya, dan sebaginya. nominal yaum 'idilhub 'Hari Valentine' (tarkib idhafiy) sebagaimana diketahui adalah harinya kaum muda, hari kasih sayang, hari istimewa yang umumnya dimanfaatkan untuk menyatakan cinta kepada lawan jenis, memberikan tanda kasih sayang kepada pasangan atau orang yang dicintainya berupa bunga, cincin tunangan, atau sekedar harapanharapan untuk masa depan mereka. Frasa ini merupakan judul utama yang ingin disampaikan kepada pengguna instagram lainnya, lalu diikuti ilustrasi di bawahnya.

Dari itu, secara keseluruhan meme ini merupakan ekspresi atau gambaran seseorang yang jelas sedang mengalami kegalauan diri, keresahan hati karena mengalami kenyataan hidup yang suram. Dia merasa tidak sebahagia seperti yang diharapkan, bahkan bisa jadi menyesali kehidupannya yang seolah tidak adil terhadapnya, ditolak pacarnya sehingga mengalami kesepian dan kesendirian. Sementara orang lain yang seusianya, pada saat yang sama, mereka bisa menikmati dan merasakan kebahagiaan, indahnya kasih sayang, bisa memadu kasih dengan pasangan pilihannya, dan sebagainya. Sementara dirinya hanya ditemani seekor kucing, sepi, dan sendiri, jauh dari orang yang dicintai.

Dengan demikian pesan yang sebenarnya ingin disampaikan pembuat meme ingin menunjukkan bahwa hidup di dunia ini ada rasa bahagia apabila sesuatu yang dianganangkan menjadi kenyataan, sebaliknya ada rasa sedih atau menderita apabila sesuatu yang diangan-angan tidak sesuai dengan kenyataan. Hal ini pasti akan membuat derita sepanjang hidupnya. Di samping itu, pesan yang ingin disampaikan pembuat meme dapat juga dimaknai bahwa anganangan itu perlu, tetapi apabila belum tercapai jangan merasa sedih, jangan mengeluh, apalagi menyalah orang lain, lalu dendam kepada orang lain, dan sebaginya.

Berikutnya adalah contoh meme yang unsur nonverbalnya mendahului unsur verbalnya, yaitu:

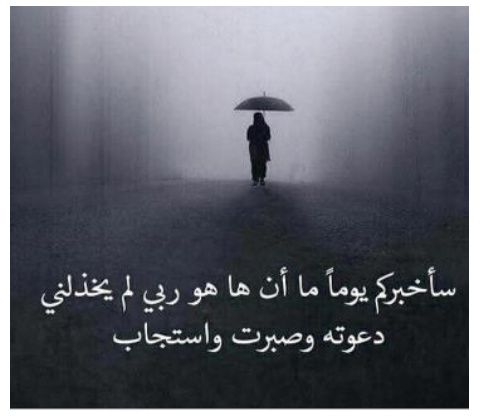

Dari contoh tersebut dapat diinterpretasikan bahwa perjuangan sosok perempuan yang sedang menempuh perjalanan menuju ke arah terang atau arah yang lebih baik dari sebelumnya meskipun di depan sana ada berbagai rintangan yang akan menghalangi langkahku (kabut di depan sana). Aku harus tetap berjalan dan terus melangkah. Perjuangannya yang panjang selalu diikuti dengan do'a dan kesabaran. Hal itu ditunjukkan dengan digunakannya FN da 'watuhu 'do'a-do'aku kepadaNya' serta FN shabartu 'dan kesabaranku', lalu dirangkai dengan klausa verbal istajaba berwazan istaf'ala 'Aku mohon Allah mengabulkan (do'aku dan lesabaranku). Dalam morfologi Arab verba yang mengacu pada wazan (timbangan) istaf ala tersebut mempunyai arti 'mohon dikabulkan'.

Dengan demikian, meme di atas bila dirangkai secara bersama-sama 
interpretasinya adalah 'Saya akan berusaha menempuh jalan hidupku sendiri (tanpa dirimu) meskipun berat, selama saya bersamamu saya selalu berdo'a dan sabar, namun kau tetap tidak memberikan kepastian hubungan kita ini, maka aku akan pergi mencari dan menemukan kehidupan yang lebih terang dan jelas. Saya yakin doadoaku dan kesabaranku selama ini pasti akan dikabulkan Allah. Itulah kekuatan (doa dan kesabaran) yang membuat saya yakin (payung) dan pasti dapat menemukan kebahagiaanku. Insyaallah nanti saya kabarkan jika saya sudah berhasil dan menemukan kebahagiaanku.

Adapun pesan yang dapat disampaikan kira-kira adalah segala sesuatu itu apabila dilakukan dengan sabar dan disertai doa kepada Allah, insyaallah pasti akan dikabulkan olehNya. Apabila kita ingin hidup damai, bahagia dunia akhirat seberapa pun panjang dan sesulit apapun harus tetap dilakukan, penderitan sepahit apapun juga harus selalu kuat dan sabar. Itulah kehidupan ini.

\section{Kesimpulan}

Dari hasil analisis data yang diperoleh dalam penelitian ini dapat disimpulkan bahwa meme dalam akun Instagram Arab @Mzajeat dan @ Iq.Shabab" dibangun atas dua unsur, yaitu unsur verbal dan nonverbal. Bersatunya dua unsur tersebut yang menjadikan meme menjadi sebuah wacana komunikasi yang utuh dan dapat dipahami makna dan pesan yang dikandung. Pemaknaan tersebut dilakukan dengan cara menganalisis unsur-unsur pembentuknya, baik unsur verbal maupun nonverbalnya.

Keterkaitan kedua unsur tersebut menjadi menarik dan mendapat perhatian yang berbeda. Pertautan antar kedua unsur serta elemen pembangunnya tesebut makna dan pesan pengguna unstagram melalui meme-memenya itu disandarkan agar dapat dipahami pemirsa atau pembaca.

\section{Daftar Pustaka}

Amrullah, Latif. 2013. "Slang dalam Situs 9gag.com: SUatu Kajian Sosiolinguistik. Tesis. Yogyakarta:Fakultas Ilmu Budaya, Universitas Gadjah Mada. Linguistik.

Badudu, J.S. 1992. Cakrawala Bahasa Indonesia II. Jakarta: Gramedia Pustaka Utama.

Bhatia, T.K. 1987. English in Advertising: Multiple Mixing and Media. In Journal of World Englishes, Vol. 6, No.1

Brown, Gillian dan George Yule. 1983. Analisis Wacana. Terjemahan I. Soetikno (1996). Jakarta: Gramedia Pustaka Utama.

Chaer, Abdul dan Leonie Agustina. 2004. Sosiolinguistik Perkenalan Awal. Jakarta: Rineka Cipta.

Cook, Guy. 2001. The Discourse of Advertising. Second Edition. London and New York: Routledge.

Crystal, David. 1987. The Cambridge Encyclopedia of Language. New York: Cambridge University Press.

1994. The Cambridge Encyclopedia of Language. New York: Cambridge City Press. 
Danesi, Marcel. 2011. Pesan, Tanda, dan Makna. Yogyakarta: Jalasutra.

Dyer, Gillian. 1989. Advertising as Communication. London and New York: Routedge.

Eriyanto. 2011. Analisis Wacana. Cetakan I. Yogyakarta: LkiS Printing Cemerlang.

Gie, The Eng (ed.). 19984. Rudyat Kipling. Yogyakarta: Karya Kencana.

Halliday, M.A.K. dan Ruqaiya Hasan. 1992. Bahasa, Konteks, dan Teks: Aspek-aspek Bahasa dalam Pandangan Semiotika Sosial. Yogyakarta: Gadjah Mada University Press.

Hasan, Tamam. 2009. Al-LughatulArabiyyah: Ma`naha wa Mabnaha. Cetakan ke-6. Cairo:'Alam al Kutub

Keraf, Gorys. 2001. Diksi dan Gaya Bahasa; Seri Retorika. Jakarta: Gramedia Pustaka Utama.

Kesuma, Tri Mastoyo Jati. 2007. Pengantar (Metode) Penelitian Bahasa. Yogyakarta: Penerbit Corasvatibooks.

Littlejohn, Stephen W., K. Foss. 2014.

$\begin{array}{llr}\text { Theories of } & \text { Human } \\ \text { Communication } & \left(9^{\text {th }} \text { ed. }\right) \text {. }\end{array}$
Singapore: CENGAGE Learning Asia, Pte.Ltd.
Van Luxemburg, Jan. dkk. 1984. Pengantar Ilmu Sastra. Diterjemahkan oleh Dick Hartoko. Jakarta: PT Gramedia.

Masrukhi. Moh. 2016. "Unsur Verbal dan Nonverbal dalam Iklan Komesrsial Media Cetak Mesir: Analisis Wacana". Disertasi. Yogyakarta: Sekolah Pascasarjana Universitas Gadjah Mada.

Mulyawan, I Wayan. 2010. Hipersemiotika Periklanan: Analisis Praktis. Denpasar: UdayanaUnibersity Press.

Ramlan, M. 1993. Paragraf: Alur Pikiran dan Kepaduannya dalam Bahasa Indonesia. Yogyakarta: Penerbit Andi Offset.

Santoso, Wahyudi Joko. 2006." Wacana Iklan Komersial Berbahsa Indoensia di Televisi. Disertasi. Yogyakarta: Universitas Gadjah Mada.

Samsuri, 1987. Analisis Bahasa. Cet. ke-7. Jakarta: Penerbit Erlangga

Sumarsono. 2011. Sosiolinguistik. Yogyakarta: Pustaka Pelajar 